\title{
PERENNIAL BYBLIS INDOOR CULTIVATION
}

Anthony (PAUL) BeLL • Mineral Wells • Texas • USA・pbell1975.pb@gmail.com

Byblis gigantea is a carnivorous plant that resides in parts of Western Australia and has been listed as critically endangered in the IUCN Red List. I here describe my experiences cultivating this species indoors for the past two years. First of all, it can be done! Some may claim that it's impossible to keep both B. gigantea and B. lamellata indoors in a temperature-controlled environment, but I have been successful (see Back Cover) and would thus like to share my experiences. I do have a small greenhouse where I am currently attempting to grow perennial Byblis to see how well they hold up in the sweltering Texas heat that we often get here in the north-central part of the state. I believe I can do it with some minor adjustments, but in this article, I want to focus on indoor cultivation. Due to their spacing requirements, I had to set a lot of other carnivorous plants to the side in order to begin my project and eventually succeed at growing these plants. With a little understanding of what it takes to make them happy, it's not difficult at all.

To start, you may wish to submit seeds to "smoke treatment". It has been suggested that by doing this method, the seeds themselves are cued by a warm stratification and along with being introduced to organic compounds (butenolides) found in smoke named "Karrikins" (Chiwocha et al. 2009; Dixon \& Roche 1996). Although I have performed this treatment many times and have had good luck in doing so, I simply prefer to soak the seeds in a solution of gibberellic acid, or GA3, as an $0.1 \%$ aqueous solution, for five days. This is a gibberellin pentacyclic diterpene acid that promotes the growth of cells and has many different effects on the development of plants. It also increases seed germination rates and is known to help B. gigantea seeds overcome dormancy. For further information regarding GA3, see Pavlis (2018). I've found that seeds that float are probably not viable, but I sow them anyway, just in case. After performing the GA3 soak, I sow seeds immediately and give them a little water using the tray method. I recommend placing a seed germination mat under the tray to provide a little warmth from the bottom of the tray.

My first $B$. gigantea seeds were purchased from a nursery in Czechoslovakia and were labeled B. gigantea "Perth Airport". I soaked the seeds in GA3 as described above, then sowed them. About a week later, I noticed I already had germination. I carefully watched over the next day or two for the others to follow. Promptly, the first two that sprouted succumbed to damping off fungus and the others never germinated. I began searching online and talking to as many people as I could but discovered that there is very little information available online about the cultivation of these wonderful plants and no one seemed to know much about it either. So, I purchased more seeds from all over the world, each time trying something different in how my setup is arranged, or a new growing technique.

When I first began this journey, I was sowing Byblis seeds in 3.5 liter pots full of medium, only to lose them to damping off fungus shortly after germination. Instead of trying to treat a huge pot of medium with fungicide (and crossing my fingers hoping I eradicated it), I would just throw all of the medium away, sterilize the pot, and then start over. It can become expensive and very timeconsuming to continuously mix up new batches of medium if damping off keeps occurring! I then switched to sowing seeds in $5 \mathrm{~cm}$ peat pots (also known as Jiffy pots). A peat pot is a small biodegradable fiber container or pot that many hobbyists use to start seeds in. Worst case scenario, it's easier to discard both the peat pot and the seed or dead seedling. But if successful, you can simply transfer the whole peat pot into the final pot in which you choose to grow the plant in. The peat pot will eventually break down into the medium and dissolve over time. But be sure to rinse the peat 
pots well with RO (reverse osmosis) or distilled water before use to remove salts. However, perennial Byblis naturally occur in places that are not totally devoid of all minerals, so no need to worry about a little buildup. My TDS (total dissolved solids) stays regularly between 20-50 parts per million, like a lot of my other carnivorous plants, and the Byblis are unphased by this.

Medium for both of the perennial Byblis species should consist of: 3:2:1 perlite:lime-free sand:peat moss. I often have to use pool filter sand, as a lot of the good stuff in my area is nowhere to be found. Using a fine hand sifter, get the smaller grains out and keep the larger ones. Be sure to rinse the medium well, continuously testing the runoff with your TDS meter. After everything is ready, take a rinsed $5 \mathrm{~cm}$ peat pot and fill it to the top with medium. Gently pack it down and place the treated perennial seed in the center, pressing very gently to ensure it stays put. You do not need to bury it.

I then place the peat pots in a $25 \times 50 \mathrm{~cm}$ tray, adding water until the pots become saturated. But do not over-water, leaving it so that there is just enough water to keep the medium moist at the surface. I will attempt to water again the next day or so, to see if the pots will absorb any more water. If not, I will discard the water as opposed to letting it sit in the tray. Using a slight draft from nearby fans gives adequate ventilation to the seedlings and makes it difficult for any fungus to take hold. Run a fan as often as possible. In one of my rooms, a fan stays on day and night. Once the plants on that shelf mature past that vulnerable stage, I continue to leave the fan on, as I am already moving in new pots to germinate the next batch of seeds. This is a balancing act of keeping good air circulation, while not letting your medium dry out. It is also worthy to note that, as adults, neither of the perennials seem to like high humidity indoors. The type of artificial lighting that I have done well with varies. I germinate my seeds under dual bulb T8 fluorescent fixtures using a bulb of each 5000k and 6500k. A photoperiod of 16 hours on and 8 hours off worked well. I have also done well with T5-HO fluorescent bulbs.

After germination, to avoid damping off from excess humidity around the seedlings, take a pinch or two of dry sand and lightly sprinkle around the plants. This will help keep the area around them from becoming overly saturated with water. Be very gentle to avoid getting sand onto the plants, as it can be rather unsightly stuck to the mucilage. As the plants continue to grow, keep a fan gently blowing and add just enough water in the trays to keep the medium moist. Continue sprinkling dry sand in the immediate area surrounding the seedlings until eventually you no longer see peat moss. You can keep the edges of the pot free of sand to help assess the soil moisture with a finger. Once your plant is about 5 to $8 \mathrm{~cm}$ tall, you are just about in the clear. After transferring to the final pot, I cover the surface with dry sand for cosmetic purposes. I believe adding sand around the seedlings, coupled with constant air flow from the fans, are key to avoid damping off.

The roots of developing B. gigantea and B. lamellata elongate very quickly, so it is advisable to employ "Slack potting", using the same medium as mentioned above in the external pot. Slack potting (Slack 1980) involves taking the peat pot that contains your seedling and placing this into a larger pot filled with media (Fig. 1). Slack potting minimizes root disturbance to the seedlings

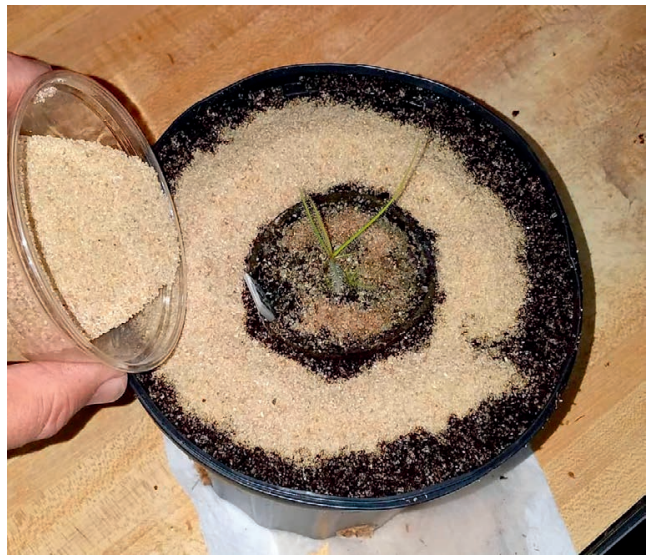

Figure 1: Carefully concealing the peat pot into the permanent pot using dry sand. 
and it also helps maintain a constant level of moisture throughout the medium surrounding the seedlings. Adrian Slack originally proposed this method for the cultivation of Drosophyllum lusitanicum and it can be used successfully for other types of plants too. Select a pot that is a minimum of 20 $\mathrm{cm}$ tall since it is harder to maintain constant moisture in smaller pots. The plants will show signs of stress if their roots don't have adequate room to grow and stretch out. I recommend mixing in a little Osmocote 15-9-12 in the medium of the larger pot. Before setting the peat pot into the 3.5 liter pot, I carefully cut the bottom of the peat pot off using a sharp razor. I then place the peat pot so that it is about $6 \mathrm{~mm}$ below the top rim of the large pot and fill in the rest with dry sand. This will conceal the peat pot and also give the plant a more natural look. My plants quickly reached maturity and flowered at approximately 7-8 months of age.

Perennial Byblis will stop sending up new leaves and flower stalks towards the end of the growing season, as they approach dormancy time. In nature this happens during the summer months, when growth rate will slow down significantly. For me, this occurs from late summer through fall, with plants waking up around early spring and actively flowering from around mid-March until around November. When growing indoors, dormancy is not a requirement and will not harm the plant if skipped. However, during this time I like to reduce watering and give them a little rest period by only supplying their watering trays with the amount of water that they will soak up in a few minutes. I then let the pots dry for a few days and repeat this procedure every week until the growing season approaches.

In preparation for spring, and to stimulate vigorous new growth, I take a pair of scissors and trim the leaves all the way back around mid-March, leaving only a couple of $\mathrm{cm}$ of the previous season's growth. It is important though to not trim back the leaves before spring, so the plants can keep photosynthesizing - and in case you wish to apply foliar feeding (yes, they will still appreciate feeding during their resting period!). However, if you're using Osmocote, as recommended above, feeding may not be necessary. After cutting the leaves back, you will soon notice new growth emerging and may even see new shoots from other sections of the rhizome, eventually growing into a very large plant.

I also repot my perennial Byblis around mid-March, at the same time that I trim the leaves. But I only repot if and when I see an excessive amount of roots protruding from the bottom of the pots, or if the plant appears to look quite large for its pot. When adults, they're fortunately not as sensitive to root disturbance as younger plants. During the repotting process, make sure to not let the roots dry out. Keep them moist at all times! Plants need to be transferred to their fresh substrate immediately after being pulled from the old medium. I recommend repotting once every two years, or every year in case you observe unsightly algae buildup on the soil surface. Algae buildup might be a sign that the plants are being kept too wet. You may trim and repot at the same time, but refrain from doing either during the growing season. With the appearance of new growth, you may also see flower scapes emerging. At this time, I recommend setting the tall pots into $2.5 \mathrm{~cm}$ of water every day for the duration of the growing season. Slightly moist medium will do nicely, but do not let the soil dry out during active growth. My plants flower from April to November.

By following the above tips, you will hopefully obtain healthy adult B. gigantea and B. lamellata that you will grow to love. If you maintain the plants properly by trimming and repotting, they will grow vigorously. You will know it is happy when it sends out an array of flowers that many plants could only wish they had!

Acknowledgements: I would like to express my thanks to Dr. Greg Allan, Cindy Chiang, and Mr. Maik Rehse. Without your willingness to communicate with me and taking your valuable time to 
respond to my messages during the last few years, I believe this journey would have been much more difficult than it has been thus far.

\section{References}

Chiwocha, S.D.S., Dixon, K.W., Flematti, G.R., Ghisalberti, E.L., Merritt, D.J., Nelson, D.C., Riseborough, J.-A.M., Smith, S.M., and Stevens, J.C. 2009. Karrikins: A new family of plant growth regulators in smoke. Plant Science 177(4): 252-256.

Dixon, K, and Roche, S. 1996. Smoke Stimulates the Germination of Many Western Australian Plants. http://anpsa.org.au/APOL2/jun96-6.html (accessed on 2 March 2019).

Pavlis, R. 2018. GA3 - Gibberellic Acid Speeds Up Seed Germination, http://www.gardenfundamentals.com/ga3-gibberellic-acid-speeds-up-seed-germination/ (accessed on 2 March 2019).

Slack, A. 1980. Species Cultivation, Drosophyllum. In: Carnivorous Plants, pp. 208-209. MIT Press, Cambridge, Mass.
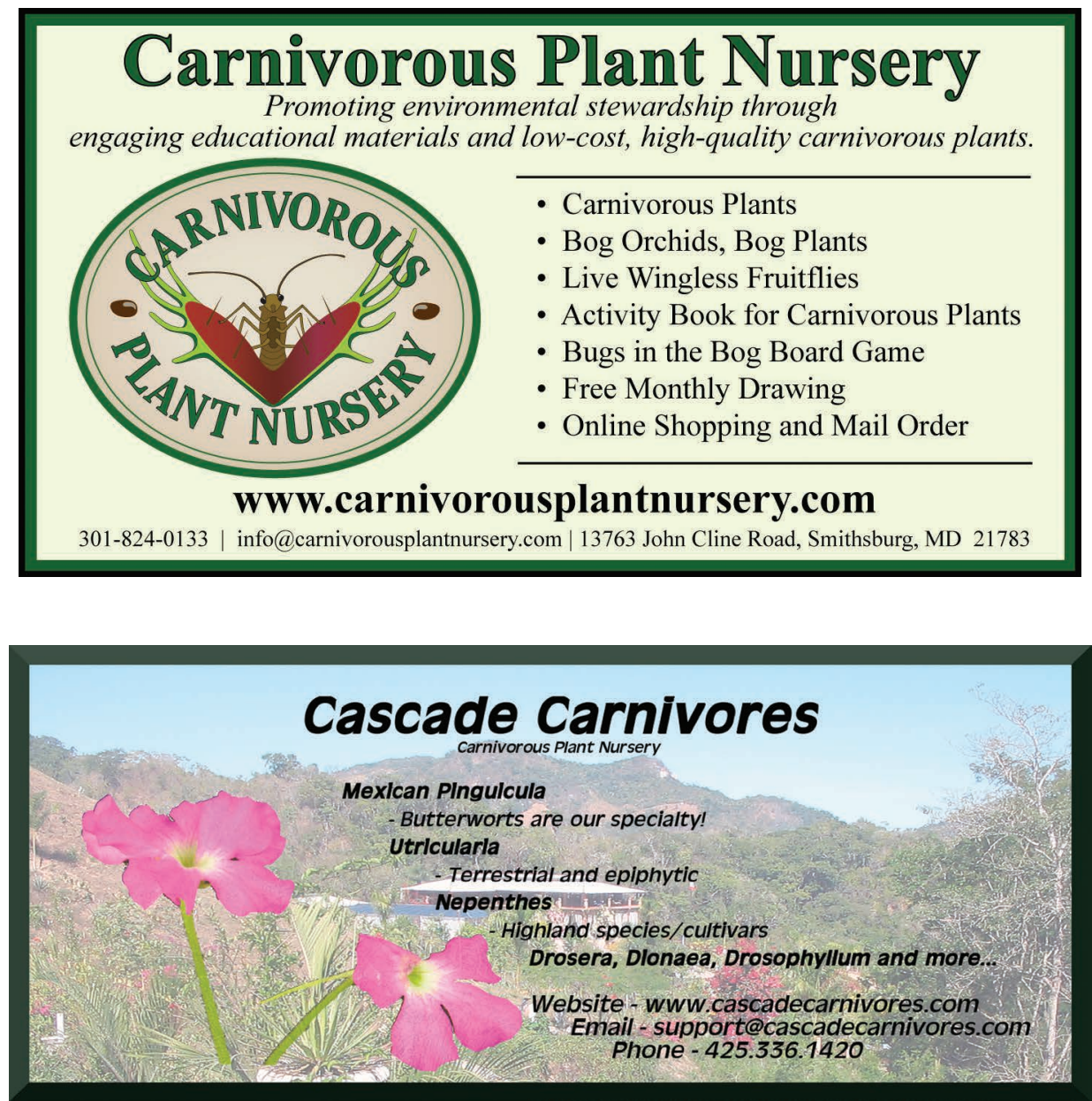


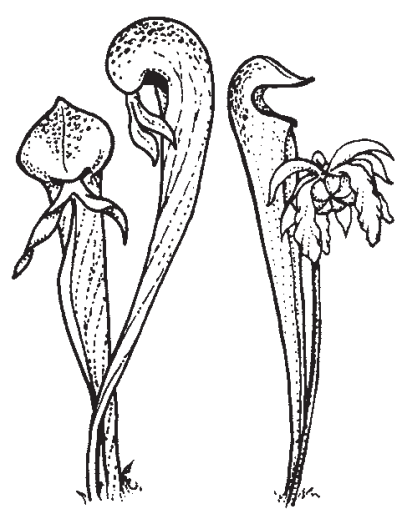

\section{CARNIVOROUS \\ PLANT \\ NEWSLETTER}

Journal of the International

Carnivorous Plant Society

www.carnivorousplants.org

Volume 48, Number 2 June 2019

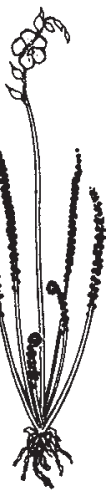

Front Cover: The beautiful flowers of Byblis rorida (center left) and Byblis pilbarana (center right). Photo by Gregory Allan. Article on page 79.

Back Cover: Byblis gigantea. Grown indoor from seed by Anthony Bell. Article on page 89.

Carnivorous Plant Newsletter is dedicated to spreading knowledge and news related to carnivorous plants. Reader contributions are essential for this mission to be successful. Do not hesitate to contact the editors with information about your plants, conservation projects, field trips, or noteworthy events. Advertisers should contact the editors. Views expressed in this publication are those of the authors, not the editorial staff.

All correspondence regarding dues, address changes and missing issues should be sent to the Membership Coordinator at the ICPS. Do not send such correspondence to the editors. Checks for subscriptions should be made to the International Carnivorous Plant Society in US funds. Dues, including a subscription, are \$30 per year.

International Carnivorous Plant Society, Inc.

2121 N. California Blvd., Suite 290

Walnut Creek, CA 94596-7351, USA

icps@carnivorousplants.org

President

Vice President

Secretary

Treasurer

Board Member

Board Member

Board Member

Membership Coordinator

Webmaster

Media Coordinator

Seed Bank Manager

CPN Editors

Managing Editor

Editor

Editor

Editor

Science Editor

Science Editor

Science Editor
Richard Nunn, richardnunn@carnivorousplants.org
John Brittnacher, john@carnivorousplants.org
Cindy Slezak, cindy@carnivorousplants.org
Daniela Ribbecke, daniela@carnivorousplants.org
Brent Jones, Conservation Director, brent@carnivorousplants.org
Jan Schlauer, Cultivar Registrar, jan@carnivorousplants.org
BobZiemer, bob@carnivorousplants.org
Cindy Slezak, cindy@carnivorousplants.org
John Brittnacher, john@carnivorousplants.org
Chad Williams, chad@carnivorousplants.org
Joe Griffin, joe@carnivorousplants.org
editor@carnivorousplants.org
Bob Ziemer
Barry Rice
Karl Herold
John Brittnacher
Andreas Fleischmann
Fernando Rivadavia
Jan Schlauer

Date of effective publication of the March 2019 issue of Carnivorous Plant Newsletter: January 30, 2019.

The ICPS is the International Cultivar Registration Authority (ICRA) for the names of cultivated carnivorous plants according to the International Code of Nomenclature for Cultivated Plants. Send relevant correspondence to the ICPS, Inc.

Carnivorous Plant Newsletter is published quarterly in March, June, September, and December by the ICPS, Inc., 2121 N. California Blvd., Suite 290, Walnut Creek, CA 94596, USA. Periodicals postage paid at Walnut Creek, CA and additional mailing offices. Postmaster: Send address changes to ICPS, Inc., 2121 N. California Blvd., Suite 290, Walnut Creek, CA 94596, USA. Printed by Allen Press, Inc., 810 E. 10th Street, Lawrence, KS 66044. Logo and masthead art: Paul Milauskas. (C) 2019 International Carnivorous Plant Society. All rights reserved. ISSN \#0190-9215 